\title{
Effects of CP 55,940 - agonist of CB1 cannabinoid receptors on ghrelin and somatostatin producing cells in the rat pancreas
}

\author{
Irena Kasacka $^{1}$, Ewa Arciszewska ${ }^{1}$, Maria Małgorzata Winnicka ${ }^{2}$, Alicja Lewandowska ${ }^{1}$ \\ ${ }^{1}$ Department of Histology and Cytophysiology, Medical University, Bialystok, Poland \\ ${ }^{2}$ Department of General and Experimental Pathology, Medical University, Bialystok, Poland
}

\begin{abstract}
Cannabinoids participate in the modulation of numerous functions in the human organism, increasing the sense of hunger, affecting carbohydrate and lipid metabolism, and controlling systemic energy balance mechanisms. Moreover, they influence the endocrine system functions, acting via two types of receptors, CB1 and CB2. The aim of the present study was to examine the number, distribution and activity of ghrelin and somatostatin producing endocrine cells in the pancreas of rats after a single administration of selective CP 55,940 agonist of CB1 receptor. The study was performed on 20 rats. Neuroendocrine cells were identified by immunohistochemical reactions, involving specific antibodies against ghrelin and somatostatin. The distribution and number of ghrelin- and somatostatin-immunoreactive cells were separately studied in five pancreas islets of each section. A performed analysis showed a decreased number of somatostatin-immunoreactive cells and a weak immunoreactivity of ghrelin and somatostatin containing neuroendocrine cells in the pancreatic islets of experimental rats, compared to control animals. The obtained results suggest that a single administration of a selective CP 55,940 agonist of CB1 receptor influences the immunoreactivity of endocrine cells with ghrelin and somatostatin expression in the pancreas islets. (Folia Histochemica et Cytobiologica 2012, Vol. 50, No. 1, 111-117)
\end{abstract}

Key words: cannabinoid, ghrelin, somatostatin, pancreas, rat

\section{Introduction}

Cannabinoids may be divided into exogenous compounds, the most common of which are D8-tetrahydrocannabinol $(\triangle 8$-THC) and the more active $\Delta$ 9-tetrahydrocannabinol ( $\triangle 9$-THC), and endocannabinoids, among which anandamide and 2-arachidonyloglycerol are the best recognized and most widely known compounds [1].

Cannabinoids act mainly via the two types of receptors: $\mathrm{CB} 1$ and $\mathrm{CB} 2$. $\mathrm{CB} 1$ receptor is localized mainly in the central nervous system, including the hypothalamus, the limbic system, brain stem nuclei,

Correspondence address: I Kasacka,

Department of Histology and Cytophysiology,

Medical University of Bialystok,

Kilinski Str. 1, 15-089 Bialystok, Poland;

tel./fax: + 488574854 58, 74855 16;

e-mail:kasacka@umwb.edu.pl the pituitary gland, as well as in the spleen, lymph nodes, the liver, the heart, the lungs and the pancreas. The peripheral CB2 receptor is associated with cells of the immune system, the spleen, the lymph nodes and bone marrow, as well as with adipocytes, keratinocytes and pancreatic islet cells [2].

The consequences of cannabinoid receptor activation include a suppressed release of neurotransmitters, an increased activity of adenylocyclase, MAP kinase (mitogen-activated protein kinase), calcium channel blocking and potassium channel activation [3].

Cannabinoids take part in the control of systemic energy balance and stimulate food intake [4]. Their central and peripheral actions stimulate appetite, cause changes in the metabolism of carbohydrates and lipid compounds and in the accumulation of fats [5]. The orexigenic activity of endocannabinoids is, first of all, associated with a large number of CB1 receptors in the hypothalamus, mainly in the arched nucleus, the ventral medial nucleus and the paraventricu- 
lar nucleus. These are the areas where appetite increasing or decreasing factors coexist [6].

Ghrelin presents with endocannabinoid-like activity, regarding the control of energy balance and food intake [7].

Ghrelin is a 28-amino acid peptide, primarily isolated in specific cells of rat gastric mucosa, but its production has also been detected in the small intestine, the pancreas, testis, placenta and, probably, also in the hypothalamus [8].

Since ghrelin was first identified in 1999, it has been the subject of numerous studies, concerning, among others, the neuroendocrine mechanisms of food intake control [9]. Through its complex interactions with neurotransmitters in the hypothalamus, ghrelin appears to be a potent regulator of feeding behavior and energy homeostasis. Experimental studies have proven that ghrelin stimulates food intake and induces weight gain.

Endocrine X/A cells of stomach fundus mucosa are the main area of ghrelin production [8]. However, in the fetal period, ghrelin-positive cells in the pancreatic islets precede their occurrence in the stomach [10]. At the end of the fetal period, and in human newborns, they constitute approximately $10 \%$ of all the cells in the islets of Langerhans, but in mature subjects, cells with ghrelin expression are very scarce (approximately 1\%) [11]. Thus, in the course of system development, ghrelin expression in the pancreas gradually decreases, while the peptide's expression in the stomach increases [12].

Ghrelin exerts a broad physiological effect via induced secretion of the growth hormone, prolactin and $\mathrm{ACTH}$, stimulation of gastric motor activity and gastric juice secretion; moreover, it supports insulin resistance and gluconeogenesis [13]. Ghrelin initiates the sense of hunger and increases appetite, resulting in body mass increase, mainly by fat tissue deposition [9].

Somatostatin (ST) is synthesized from a 92-amino acid preprosomatostatin precursor molecule that is processed to generate somatostatin-14 and somatostatin-28. Somatostatin-14 is predominantly found in the stomach, the pancreatic islets, and enteric neurons, whereas somatostatin-28 is the major form in the small intestine. Somatostatin, which is present in gastric oxyntic and pyloric D cells, inhibits acid secretion by acting directly on parietal cells and, indirectly, by inhibiting histamine secretion from enterochromaffin-like cells and gastrin secretion from $\mathrm{G}$ cells. The wide distribution of somatostatin and of its receptor subtype family in the human body explains the great variety of physiological mechanisms in which this peptide hormone is involved [14]. Somatostatin, an inhibitory neuropeptide, occurs in regions of the central nervous system, the peripheral nerves and the gastrointestinal tract, being involved in motor, cognitive, autonomic, and neuroendocrine processes [15].
Somatostatin release can be stimulated by a variety of hormones, neuropeptides, neurotransmitters, cytokines, growth factors and nutrients. For example, the growth hormone-releasing hormone (GHRH), neurotensin and the corticotropin-releasing hormone $(\mathrm{CRH})$ are all potent stimulators of ST secretion in several tissues. On the other hand, the neurotransmitters: $\gamma$ aminobutyric acid (GABA), and opiates generally, inhibit ST secretion.

In the pancreas, somatostatin is produced by delta cells of the pancreatic islets, where it exerts local effects, inhibiting insulin and glucagon secretion [16].

The effects of somatostatin and ghrelin are antagonistic to growth hormone secretion; however, there are several control mechanisms where these effects are convergent [17].

No data was found in the available literature regarding the behavior of endocrine cells which produce ghrelin and somatostatin in the pancreatic islets as a result of cannabinoid effects. Besides, much attention has recently been paid in pre-clinical and clinical studies to the synthetic ligands of cannabinoid $\mathrm{CB} 1$ and $\mathrm{CB} 2$ receptors.

Taking the above-mentioned issues into account, as well as considering the occurrence of cannabinoid receptors in the pancreas, we decided to study the effects exerted by the selective agonist CP 55,940 of CB1 receptor on ghrelin- and somatostatin-producing cells in rat pancreatic islets.

\section{Material and methods}

Experimental model. The study was performed on 20 young male Wistar rats, each weighing 160-190 g. The rats were housed individually in lighted and ventilated conditions at room temperature and maintained day and night rhythm. The animals had free access to standard granulated chow, and drinking water was available ad libitum. Study assumptions, its aim and schedule and the mode of animal treatment were approved by the Local Ethics Committee for Animals, Medical University of Bialystok (26/2001).

The rats were divided into two groups: a control group of five animals, injected with vehicle solution, and an experimental group of 15 animals, injected once with an intraperitoneal dose of $0.25 \mathrm{mg} / \mathrm{kg} \mathrm{CP} \mathrm{55,940,} \mathrm{dissolved} \mathrm{in} \mathrm{dim-}$ ethyl sulphoxide (DMSO).

Histology. The method of experimental material collection and fixation. Four hours after the injection, the animals were decapitated under pentobarbital anesthesia (50 mg/kg b.w.). The pancreas was immediately removed, fixed in Bouin's fluid, and embedded in paraffin in a routine way. The specimens were cut into $4 \mu \mathrm{m}$ slices (Leica 2025 Autocut) and stained by hematoxylin-eosin $(\mathrm{H}+\mathrm{E})$ for general histological examination. 
Table 1. Used antibodies

\begin{tabular}{|c|c|c|c|c|c|c|}
\hline No & Antibodies & Host & Dilution & $\begin{array}{c}\text { Time } \\
\text { and temperature } \\
\text { primary incubation }\end{array}$ & $\begin{array}{c}\text { Antigen } \\
\text { retrevial } \\
(\mathbf{p H})\end{array}$ & $\begin{array}{c}\text { Positive } \\
\text { control }\end{array}$ \\
\hline 1. & $\begin{array}{c}\text { GHRELIN Rat } \\
\text { H 031-31 }\end{array}$ & Rabbit & $1: 10,000$ & $\begin{array}{c}24 \mathrm{~h} \\
+4^{\circ} \mathrm{C}\end{array}$ & $\begin{array}{c}\text { Target retrieval } \\
\text { solution } \\
\mathrm{pH}=9.0\end{array}$ & Rat gastric glands \\
\hline 2. & PHOENIX Pharmaceutical INC & & & $\begin{array}{c}24 \mathrm{~h} \\
+4^{\circ} \mathrm{C}\end{array}$ & $\begin{array}{c}\text { Target retrieval } \\
\text { solution } \\
\mathrm{pH}=9.0\end{array}$ & Human pancreatic islets \\
& SOMATOSTATIN & Rabbit & $1: 20,000$ & & & \\
\hline
\end{tabular}

Identification of Diffuse Neuroendocrine System (DNES) cells by immunohistochemical methods. An immunohistochemical reaction was performed on paraffin pancreas sections of the studied animals to identify ghrelin and somatostatin in neuroendocrine cells. The specific antibodies against ghrelin and ST were applied in the study (Table 1). The paraffin blocks were cut into $4-\mu \mathrm{m}$ sections and mounted onto Superfrost Plus slides (Menzel, Braunschweig, Germany) and dried overnight at $37^{\circ} \mathrm{C}$, followed by 1 hour at $60^{\circ} \mathrm{C}$.

A NovoLink Polymer Detection System (No: RE7150-K) by Leica Microsystems was used in the immunohistochemical study. Immunostaining was performed using the protocol as described below [18]. The sections were deparaffinized in xylene and rehydrated in decreasing concentrations of pure ethanol. Then the sections were subjected to pre-treatment for antigen retrieval in a pressure chamber, heating for $1 \mathrm{~min}$ at $21 \mathrm{psi}$ at $125^{\circ} \mathrm{C}$ and using Buffer Retrieval (Dako, Glostrup, Denmark) (Table 1). After being cooled down to room temperature, the sections were incubated with Peroxidase Blocking Reagent for 5 minutes to block endogenous peroxidase activity. All the primary antibodies were diluted, using the same antibody diluent (S0809, Dako, Glostrup, Denmark) (Table 1).

The sections were incubated overnight at $4^{\circ} \mathrm{C}$ in a humidified chamber with the diluted antibodies (see Table 1), followed by incubation with NovoLink Polymer (conjugated to horseradish peroxidase-labeled polymer). Bound antibodies were visualized by 1-min incubation with liquid 3,3'-diaminobenzidine substrate chromogen. The sections were finally counterstained in hematoxylin QS (Vector, $\mathrm{H}$ - 3404), mounted, and evaluated under a light microscope. Appropriate washing with Wash Buffer S 3006 (Dako, Glostrup, Denmark) was performed between each step.

Control reactions were simultaneously performed. In the negative control, the specific antibodies were replaced by normal rabbit serum (Vector Laboratories, Burlingame, CA, USA) at respective dilutions. All the performed control reactions gave negative results.

A positive control was done for specific tissue, recommended by the producer; for rat ghrelin - pylorus, for somatostatin - D cells of human pancreatic islets.
Quantitative analysis. The results of immunoreactive endocrine (IRE) cells with ghrelin and somatostatin (D) expression were sought, and their topography was observed. The dark brown positive cells on a section were separately counted in five pancreas islets of each section at a magnification of $200(20 \times$ the lens and $10 \times$ the eyepiece $)$. Five sections of each rat (five control and 15 experimental) were analyzed. The average number of IRE cells from five pancreatic islets, randomly selected in each specimen, was the IRE cell number in each animal. The cell count was expressed as the mean number of ghrelin-immunopositive and somatostatin-positive cells per section. The numbers of cells were calculated by a computer.

Statistical analysis. All the presented data were statistically analyzed by means of the Statistica Version 7.0 software computer package. Descriptive statistics (mean, SD) was calculated for ghrelin-positive and somatostatin-positive cells numbers. The obtained results were expressed as means \pm \pm SD. The corresponding mean values were computed automatically; significant differences were determined by Student's $t$-test; $\mathrm{p}<0.05$ was taken as the level of significance.

\section{Results}

Routine histological studies showed no histopathological changes in pancreas morphology.

\section{Location, morphology and immunohistochemical characteristics of neuroendocrine (NE) cells in the pancreases of control and study rats}

The immunohistochemical studies revealed a positive reaction in the cytoplasm of endocrine pancreatic cells in all the examined animals, indicating that the antibody reacted against the antigens in ghrelin- and somatostatin-containing cells, recognizing their location in the pancreatic islets.

\section{Ghrelin-immunopositive cells}

In the pancreases of both the control and the experimental rats, only single ghrelin-immunoreac- 
tive cells were observed, being peripherally located in the islets of Langerhans. They were predominantly large and distinguished by their round or oval shape.

Ghrelin staining intensity was high in the pancreases of the control animals, and distinctly lower in those of the experimental group (Figures 1A, B).

Quantitative measurements indicated a comparable number of cells with positive reaction to the antibodies against ghrelin in the control and study rats ( 0.7 cells per section).

\section{Somatostatin-immunopositive cells}

The distribution density of ST-immunoreactive cells was significantly higher in the pancreases of the studied animals vs. the distribution density of ghrelin-positive cells. Somatostatin-positive cells were mostly distributed in the peripheral region of Langerhans islets and only a few of them were observed at pancreas islet centers. Single ST-immunopositive cells were scattered in the exocrine part of the pancreas (Figure 2). D cells were distinctive by their shape diversification, from fusiform to round, pyramidal or flask shapes, with frequently observed multiform cytoplasmic process, extending onto other nearby cells. This was seen especially in the pancreases of the control animals (Figures 3A, B). The majority of D-cells in the control rat pancreases showed a moderate immunostaining for somatostatin, although the staining intensity for ST in the same cells was high or weak (Figure 4A). In microscopic images of study group rat pancreases, weaker somatostatin expression was seen vs. the control animals (Figure 4B).

A computer analysis of ST-immunoreactive cells demonstrated a statistically significant decrease in the number of $\mathrm{D}$ cells in rat pancreases after a single administration of selective agonist of CB1 - CP 55,940 receptor $(7.94 \pm 3.56$ cells per section $)$ vs. the control animals $(12.77 \pm 4.48$ cells per section $)$ (Table 2).

Table 2. Number of ghrelin- and somatostatin-immunoreactive NE cells in the pancreas of control and experimental rats (mean $\pm \mathrm{SD})$

\begin{tabular}{|l|c|c|c|}
\hline & $\begin{array}{c}\text { Control rats } \\
\text { Cells per } \\
\text { section } \pm \text { SD }\end{array}$ & $\begin{array}{c}\text { Studied rats } \\
\text { Cells per } \\
\text { section } \pm \text { SD }\end{array}$ & p \\
\hline Ghrelin & 0.7 & 0.7 & $\mathrm{p}<0.05$ \\
\hline Somatostatin & $12.77 \pm 4.48$ & $7.94 \pm 3.56$ & $\mathrm{p}<0.05$ \\
\hline
\end{tabular}

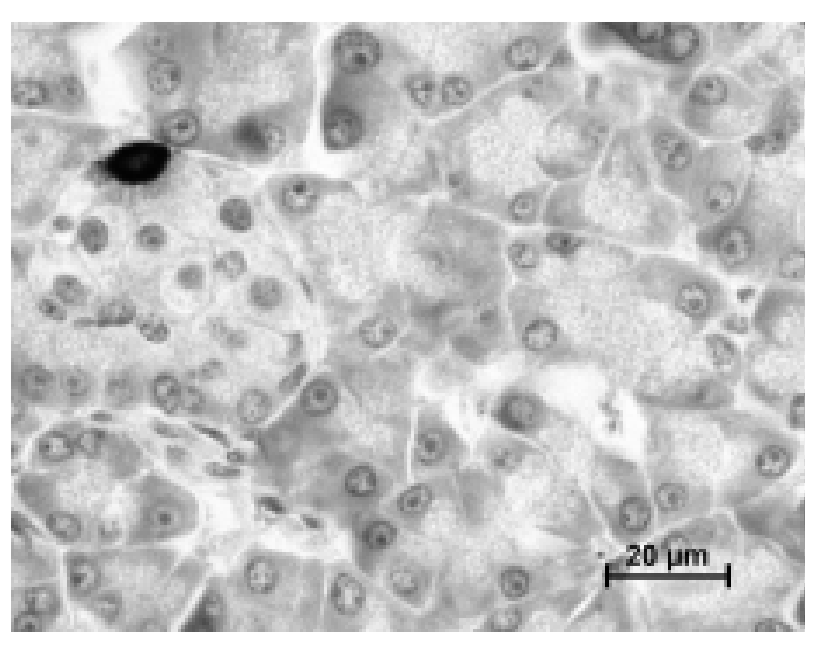

Figure 2. Single ST-immunopositive cell in the exocrine part of the pancreas of experimental rat. Magnification $\times 400$

Figure 1. Individual ghrelin immunoreactive cells in the
pancreatic islets of control $(\mathbf{A})$ and experimental rats $(\mathbf{B})$

Figure 1. Individual ghrelin immunoreactive cells in the
pancreatic islets of control (A) and experimental rats (B). Magnification $\times 400$
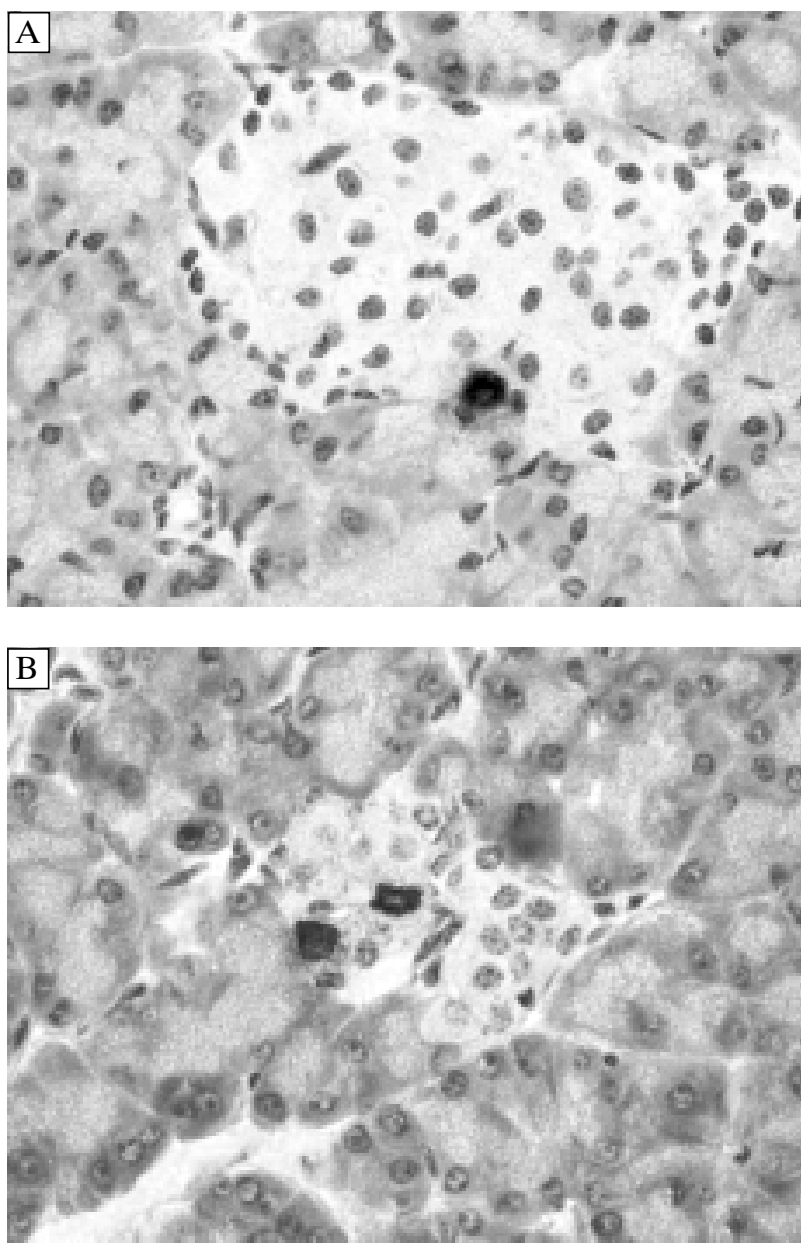

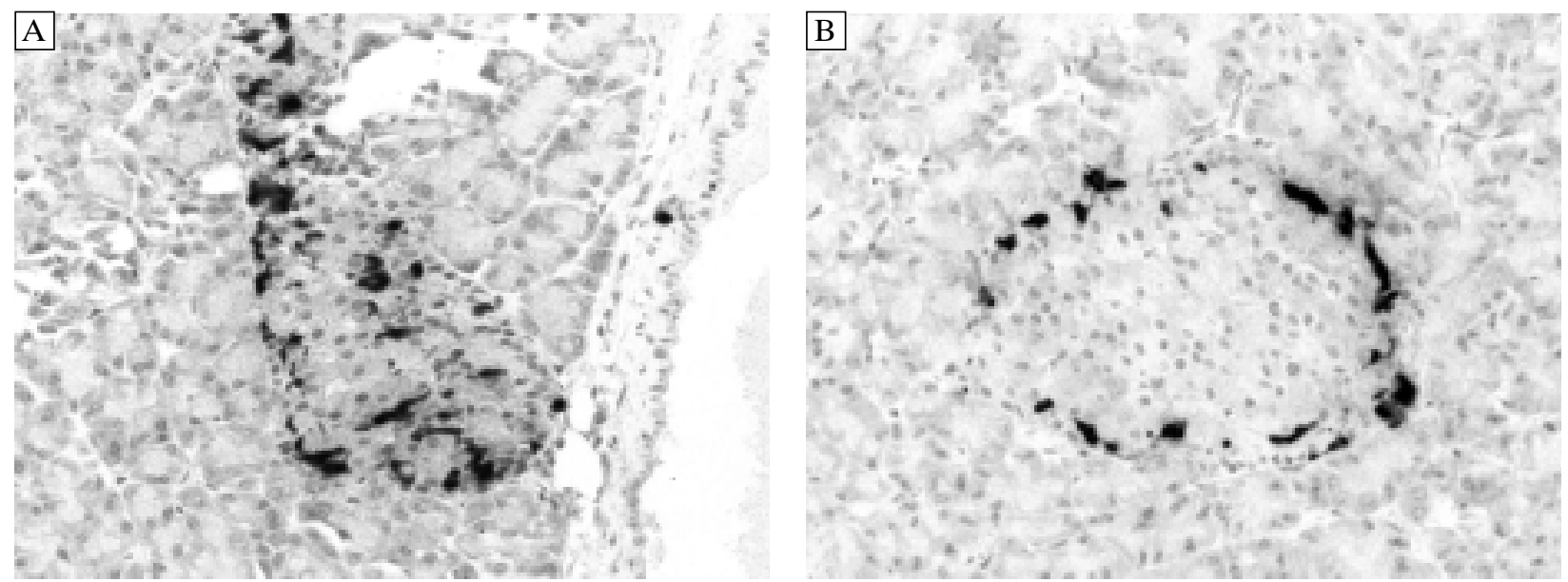

Figures 3 A and B. Variety of shapes and cytoplasmic process of somatostatin-immunopositive cells in the pancreases of control rats. Magnification $\times 200$
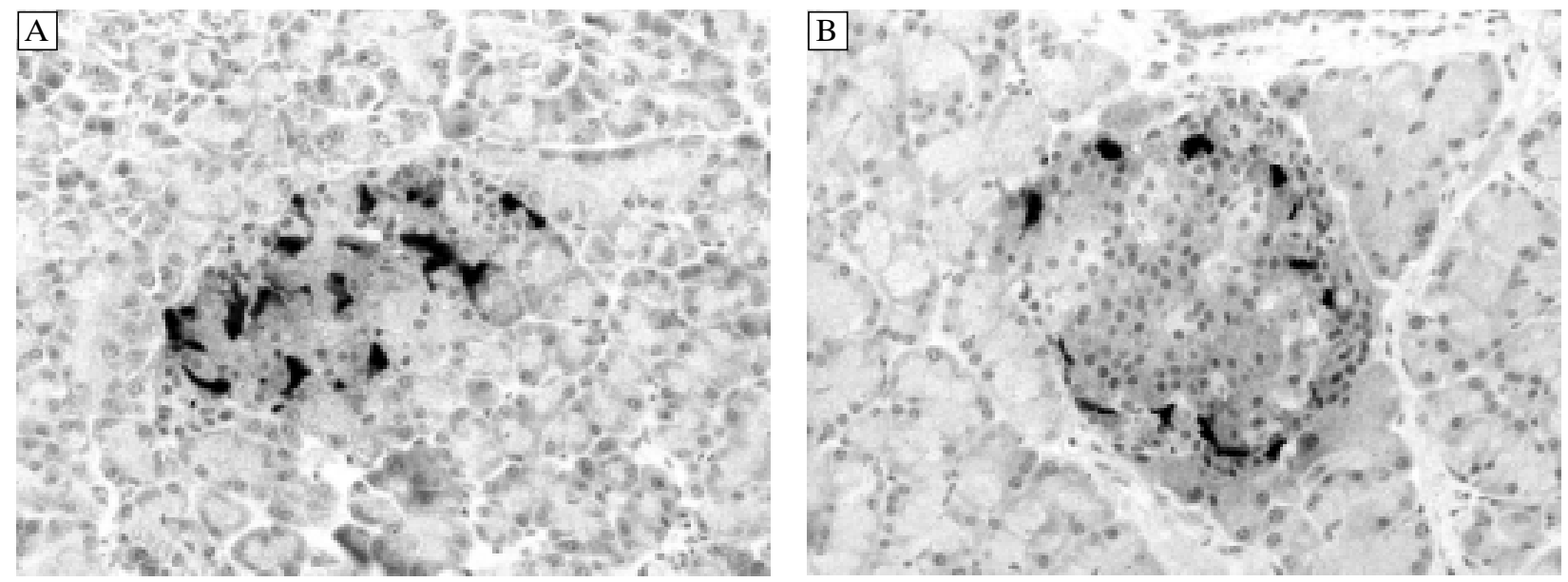

Figures 4 A and B. Somatostatin immunopositive reaction in the cytoplasm of pancreas D cells; (A) control and (B) experimental rats. Magnification $\times 200$

\section{Discussion}

The type of ghrelin-producing cells in pancreatic islets has long been controversial. Date et al. [19] postulated co-localization of ghrelin in the glucagon-producing cells in human and rat pancreas. The studies of Volante et al. [20] have proven that, in man, ghrelin is produced in beta cells of the pancreatic islets. It follows from the latest reports that this hormone is produced by epsilon cells, which constitute a separate cellular population of pancreatic islets [21], originating from the same precursor cells as do beta cells [22].

The distribution of cannabinoid receptors within the area of the islets of Langerhans in man and rat is fairly specific. In humans, CB1 receptor occurs in alpha and beta cells, as it does in mice and rats, while $\mathrm{CB} 2$ receptor in man is localized in delta cells and in animals in beta cells [22].
Cannabinoids are substances which modulate a number of functions in the human body. Their effects are sedative and analgesic, improving the memory and learning processes. They play a huge role in energy balance control and food intake stimulation [23] and participate in the regulation of endocrine cell activity [3].

The reduced number of somatostatin-producing cells, as observed in the performed studies, with their decreased immunoreactivity and weaker immunoreactivity of ghrelin-like cells, indicates a clear effect of a single dose of CP 55,940 agonist of CB1 receptor on the studied endocrine cells of rat pancreatic islets.

No data was found in the available literature regarding the behavior of ghrelin- and somatostatinproducing cells under the influence of cannabinoids; therefore, an analysis of the results, obtained in the reported study, is difficult. 
Ghrelin, secreted by cells of the pancreatic islets, exerts a local effect, and also affects the target cells localized in other organs.

A correlation has been demonstrated between ghrelin concentration and the effects of cannabinoids [24] which is associated with the mechanisms which are at the base of appetite control. A key role is played in this process by the hypothalamic AMP-protein kinase (AMPK), which is a specific factor of energy balance control at the cellular level by suppressing anabolic and stimulating catabolic processes [25]. The increased activity of AMPK results from the orexigenic action of ghrelin and cannabinoids, where the stimulatory effect of ghrelin on AMPK takes place exclusively in the presence of CB1 in the hypothalamus. The presence of CB1 receptor is necessary to induce an enhanced orexigenic effect of cannabinoids. An experiment on mice with CB1 knockout has demonstrated a total blocking of ghrelin's orexigenic effect, which could be an indication of the combined action of endocannabinoids and ghrelin [26].

A stimulation of CB1 receptor by cannabinoids, both with elevated and reduced glucose levels, causes an increased secretion of insulin [2]. Ghrelin plays a vital role in this process, causing an increased concentration of calcium ions in beta cells, which, in consequence, results in a higher insulin secretion rate [19]. However, the opinions of researchers regarding the effects of ghrelin on insulin secretion are somewhat divergent. Broglio et al. [27] found reduced insulin levels in the blood of patients after ghrelin administration, while Kamergai et al. [28], in studies on rats, did not see significant changes in the concentration of plasma insulin. The above data indicates that ghrelin controls the secretory function of pancreatic islets via endocrine and/or paracrine mechanisms.

The system of endocannabinoids, locally produced within the area of pancreatic islets, is unquestionably highly significant in the control of endocrine cell metabolism of the pancreas. Evidence for the above assumption may be sought in the presence of certain enzymes, including monoacylglycerol lipase (MAGL), fatty acid amide hydrolase (FAAH), and diacylglycerol lipase (DAGL), associated with the synthesis or degradation of cannabinoids in the endocrine part of the pancreas [22].

It may be supposed that the reduced immunoreactivity of ghrelin-positive cells, as observed in our studies, could be related to a lower production of ghrelin, result of applied cannabinoid. A study by Cani et al. [29] confirms the above observations, having demonstrated that an administration of a single dose of SR141716, a cannabinoid receptor antagonist, reduces ghrelin levels in plasma.
The pancreas undergoes complex regulatory processes, in which nervous and hormonal factors play a significant role, as well as local regulatory factors, which are decisive for the proper functioning of the organ, including amylin secreted by beta cells [30], platelet-derived growth factor (PDGF), and tumor necrosis factor (TNF) [31]. It may be assumed that these compounds can mediate ghrelin and somatostatin release.

The reduced numbers of D cells, as observed in the reported study, may have been caused by an enhanced secretion or disturbed synthesis of somatostatin under the influence of CP 55,940 agonist of CB1 receptor. Rettori et al. [32] found in their study a reduced secretion of the growth hormone, both from the normal pituitary gland of man, as well as from cells of somatotropic adenomas, as an effect of cannabinoid activity, which the authors associated with stimulation of somatostatin release in the hypothalamus.

It follows from the study by Bermúdez-Silva et al. [22] that endocannabinoids, produced in pancreatic islets and being the agonists of $\mathrm{CB} 1$ receptor, induce an increased secretion of glucagon and somatostatin. Delta cells in rats do not demonstrate CB1 expression; therefore, according to the authors, the increased secretion of somatostatin is a negative feed-back mechanism mediated by glucagon-dependent somatostatin release. In turn, a stimulation of CB2 receptor in isolated human pancreases reduces insulin secretion, most probably without somatostatin mediation.

Ours was the first study undertaken to describe changes in the activity of ghrelin and somatostatin producing endocrine cells in the pancreas to a single administration of selective CP 55,940 agonist of CB1 receptor.

From the present study, we conclude that cannabinoids change immunoreactivity of the ghrelin and somatostatin producing cells in pancreatic islets. However, the modulation of the pancreatic endocrine part, following the application of agonists for cannabinoid receptors, requires further investigation.

\section{References}

1. Di Marzo V, Ligresti A, Morera E, Nalli M, Ortar G. The anandamide membrane transporter. Structure-activity relationships of anandamide and oleoylethanolamine analogs with phenyl rings in the polar head group region. Bioorg Med Chem. 2004;12:5161-5169.

2. Bermúdez-Silva FJ, Serrano A, Diaz-Molina FJ et al. Activation of cannabinoid CB1 receptors induces glucose intolerance in rats. Eur J Pharmacol. 2006;531:282-284.

3. Ranganathan M, D'Souza DC. The acute effects of cannabinoids on memory in humans: a review. Psychopharmacology (Berl). 2006;188:425-444.

4. Komorowski J, Stepień H. The role of the endocannabinoid system in the regulation of endocrine function and in the con- 
trol of energy balance in humans. Postepy Hig Med Dosw. 2007;61:99-105.

5. Cota D, Marsicano G, Tschöp M et al. The endogenous cannabinoid system affects energy balance via central orexigenic drive and peripheral lipogenesis. J Clin Invest. 2003;112:423-431 .

6. Gamber KM, Macarthur H, Westfall TC. Cannabinoids augment the release of neuropeptide $\mathrm{Y}$ in the rat hypothalamus. Neuropharmacology. 2005;49:646-652.

7. Van Thuijl H, Kola B, Korbonits M. Appetite and metabolic effects of ghrelin and cannabinoids: involvement of AMP-activated protein kinase. Vitam Horm. 2008;77:121-148.

8. Date Y, Kojima M, Hosoda H et al. Ghrelin, a novel growth hormone-releasing acylated peptide, is synthesized in a distinct endocrine cell type in the gastrointestinal tracts of rats and humans. Endocrinology. 2000;141:4255-4261.

9. Peeters TL. Ghrelin: a new player in the control of gastrointestinal functions. Gut. 2005;54:1638-1649.

10. Chanoine JP, Wong AC. Ghrelin gene expression is markedly higher in fetal pancreas compared with fetal stomach: effect of maternal fasting. Endocrinology. 2004;145:3813-3820.

11. Wierup N, Svensson H, Mulder H, Sundler F. The ghrelin cell: a novel developmentally regulated islet cell in the human pancreas. Regul Pept. 2002;107:63-69.

12. Kotunia A, Zabielski R. Ghrelin in the postnatal development of the gastrointestinal tract. J Physiol Pharmacol. 2006;57:97-111.

13. Broglio F, Prodam F, Me E et al. Ghrelin: endocrine, metabolic and cardiovascular actions. J Endocrinol Invest. 2005;28:23-25.

14. Taniyama Y, Suzuki T, Mikami Y, Moriya T, Satomi S, Sasano H. Systemic distribution of somatostatin receptor subtypes in human: an immunohistochemical study. Endocr J. 2005;52: 605-611.

15. Olias G, Viollet C, Kusserow H, Epelbaum J, Meyerhof W. Regulation and function of somatostatin receptors. J Neurochem. 2004;89:1057-1091.

16. Singh V, Brendel MD, Zacharias S et al. Characterization of somatostatin receptor subtype-specific regulation of insulin and glucagon secretion: an in vitro study on isolated human pancreatic islets. J Clin Endocrinol Metab. 2007;92: 673-680.

17. Baiguera S, Conconi MT, Guidolin D et al. Ghrelin inhibits in vitro angiogenic activity of rat brain microvascular endothelial cells. Int J Mol Med. 2004;14:849-854.

18. Tsutsumi Y, Serizawa A, Kawai K. Enhanced polymer onestep staining (EPOS) for proliferating cell nuclear antigen (PCNA) and Ki-67 antigen: application to intra-operative frozen diagnosis. Pathol Int. 1995;45:108-115.

19. Date $Y$, Nakazato M, Hashiguchi $S$ et al. Ghrelin is present in pancreatic alpha-cells of humans and rats and stimulates insulin secretion. Diabetes. 2002;51:124-129.
20. Volante M, Allía E, Gugliotta P et al. Expression of ghrelin and of the GH secretagogue receptor by pancreatic islet cells and related endocrine tumors. J Clin Endocrinol Metab. 2002;87:1300-1308.

21. Wierup N, Yang S, McEvilly RJ, Mulder H, Sundler F. Ghrelin is expressed in a novel endocrine cell type in developing rat islets and inhibits insulin secretion from INS-1 (832/13) cells. J Histochem Cytochem. 2004;52:301-310.

22. Bermúdez-Silva FJ, Suárez J, Baixeras E et al. Presence of functional cannabinoid receptors in human endocrine pancreas. Diabetologia. 2008;51:476-487.

23. Harrold JA, Williams G. The cannabinoid system: a role in both the homeostatic and hedonic control of eating? BrJ Nutr. 2003;90:729-734.

24. Tucci SA, Rogers EK, Korbonits M, Kirkham TC. The cannabinoid CB1 receptor antagonist SR141716 blocks the orexigenic effects of intrahypothalamic ghrelin. Br J Pharmacol. 2004;143:520-523.

25. Andersson U, Filipsson K, Abbott CR et al. AMP-activated protein kinase plays a role in the control of food intake.J Biol Chem. 2004;279:12005-12008.

26. Kola B, Farkas I, Christ-Crain $M$ et al. The orexigenic effect of ghrelin is mediated through central activation of the endogenous cannabinoid system. PLoS One. 2008;3:e1797.

27. Broglio F, Arvat E, Benso A et al. Ghrelin, a natural GH secretagogue produced by the stomach, induces hyperglycemia and reduces insulin secretion in humans. J Clin Endocrinol Metab. 2001;86:5083-5086.

28. Kamegai J, Tamura H, Shimizu T, Ishii S, Sugihara H, Wakabayashi I. Chronic central infusion of ghrelin increases hypothalamic neuropeptide $\mathrm{Y}$ and Agouti-related protein mRNA levels and body weight in rats. Diabetes. 2001;50:2438-2443.

29. Cani PD, Montoya ML, Neyrinck AM, Delzenne NM, Lambert DM. Potential modulation of plasma ghrelin and glucagon-like peptide-1 by anorexigenic cannabinoid compounds, SR141716A (rimonabant) and oleoylethanolamide. BrJ Nutr. 2004;92:757-761.

30. Hull RL, Westermark GT, Westermark P, Kahn SE. Islet amyloid: a critical entity in the pathogenesis of type 2 diabetes. J Clin Endocrinol Metab. 2004;89:3629-3643.

31. Warzecha Z, Dembiński A, Ceranowicz P et al. Immunohistochemical expression of FGF-2, PDGF-A, VEGF and TGF beta RII in the pancreas in the course of ischemia/reperfusion-induced acute pancreatitis. J Physiol Pharmacol. 2004;55:791-810.

32. Rettori V, Aguila MC, Gimeno MF, Franchi AM, McCann SM. In vitro effect of delta 9-tetrahydrocannabinol to stimulate somatostatin release and block that of luteinizing hormone-releasing hormone by suppression of the release of prostaglandin E2. Proc Natl Acad Sci USA. 1990;87:10063-10066.

Submitted: 7 April, 2011

Accepted after reviews: 14 November, 2011 